\title{
Human platelet monoamine oxidase activity in health and disease: a review
}

\author{
M SANDLER, MA REVELEY,* AND VIVETTE GLOVER \\ From the Bernhard Baron Memorial Research Laboratories and Institute of Obstetrics and Gynaecology, \\ Queen Charlotte's Maternity Hospital, Goldhawk Road, London W6 OXG, UK
}

SUMMARY The most readily available source of monoamine oxidase in man is the platelet, although only the B form of the enzyme is represented in this site. Platelet activity is higher in women than $\omega$ in men. The enzyme activity is generally stable and is partly under genetic control. There is some $\stackrel{+}{\omega}$ evidence that individuals with low activity have a higher psychiatric morbidity than those with high activity.

Despite some negative studies, the consensus of publications dealing with schizophrenia, migraine, 을 and alcoholism find that mean platelet monoamine oxidase activity in the patient group is lower than $\vec{r}$ in the controls. Values are raised in unipolar depression. Technical differences, or patient or control group heterogeneity, might well account for the absence of unanimity in the literature. A considerable $\stackrel{\vec{\Omega}}{\neg}$ degree of overlap between patient and control values, whatever the clinical diagnosis, appears to be the standard finding.

Apart from these neuropsychiatric disturbances, platelet monoamine oxidase activity is raised in megaloblastic anaemia and reduced in iron deficiency anaemia. Although altered enzyme activity values may be linked to abnormal platelet populations in some of the haematological disorders discussed, in general the causes of abnormal platelet monoamine oxidase activity are unknown.

The insoluble mitochondrial enzyme, monoamine oxidase (MAO) (EC.1.4.3.4), is the subject of a voluminous literature (for review, see refs 1-3). Most of the biologically active monoamines it numbers among its substrates are either known neurotransmitters or neurotransmitter candidates. Thus, even though MAO is widely distributed through the body, it is not surprising that its possible role in neuropsychiatric disorders has figured most prominently in these research publications.

One of the major constraints to its direct study in man is the problem of accessibility. Although occasional attempts have been made to quantify enzyme activity in biopsy samples from a variety of different sources, including jejunal mucosa, ${ }^{45}$ skin fibroblasts, ${ }^{6}$ buccal scrapings, ${ }^{7}$ and muscle, ${ }^{8}$ for most practical purposes the only readily accessible source of the enzyme for routine studies derives from certain formed elements of the blood. Although lymphocytes, which may be difficult to harvest, have on occasion been used as enzyme source, ${ }^{9}$ the blood platelet, which is relatively easy to obtain in pure

* Present address : Department of Psychiatry, Institute of Psychiatry, De Crespigny Park, Denmark Hill, London SE5 8AF. preparation, has been the tissue of choice to an overwhelming extent.

Not that the human platelet enzyme is ideal to provide an insight into the status of central nervous system MAO. A widely accepted working classifi- 홍 cation of the enzyme into A and B forms exists, based on the differential inhibitory ability of the drug clorgyline; ${ }^{10}$ type $A$ is defined as the form 8 sensitive to clorgyline, and this oxidatively deamin- 3 ates noradrenaline and 5-hydroxytryptamine but not $\mathrm{O}$ phenylethylamine; type B is preferentially inhibited by deprenyl ${ }^{11}$ and selectively deaminates phenyl- $\frac{}{2}$ ethylamine ${ }^{12}$ and tele-methylhistamine ${ }^{13}$ rather than $\frac{\bar{N}}{N}$ noradrenaline and 5-hydroxytryptamine. Tyramine $\sigma$ and dopamine are substrates for both forms. It is N quite clear that the human platelet is a pure source of MAO B, ${ }^{14}$ as, for that matter, is human lymphocyte. ${ }^{9} \mathrm{O}$ Although the human brain has a relatively high MAO B content ${ }^{15}$ and dopamine is predominantly

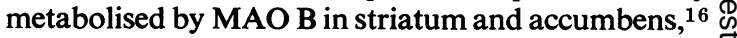
substantial MAO A activity is also present. Even so, and as we discuss below, changes in platelet activity have been noted in a variety of human disease states, $\overrightarrow{\mathbb{D}}$ and, in the few instances where it is possible to make $\frac{\pi}{\mathbb{D}}$ direct comparison, it has been difficult to detect any 
correlation between brain and platelet enzyme status. ${ }^{17}$ The absence of an immediate explanation for any of the platelet enzyme changes that we detail does not, however, prevent us from employing them empirically for diagnosis or patient management.

It should be pointed out here that several studies of platelet MAO have also measured a plasma amine oxidase $^{18} 19$ quite distinct from MAO but with a number of overlapping properties. Like MAO B, it actively oxidises benzylamine but metabolises other monoamines poorly. ${ }^{20}$ Whereas MAO is a mitochondrial flavoprotein, benzylamine oxidase, ${ }^{21}$ as we must call this enzyme without prejudicing the question of what its true natural substrates are, is soluble and copper-dependent. Apart from plasma, this enzyme is widespread, being concentrated particularly in blood vessel walls but absent from brain and liver parenchyma. ${ }^{22}{ }^{23}$ Benzylamine oxidase and MAO B can be distinguished, where necessary, by the judicious use of selective inhibitors. ${ }^{22}$

\section{Assay procedures and variability among studies}

One recurring problem throughout the platelet MAO literature is an apparent lack of reproducibility between studies. This is particularly true of work on schizophrenia. Of the variety of explanations put forward to account for these discrepancies, ${ }^{24}$ one obvious one is technical: a bewildering variety of approaches to the assay of platelet activity has been recorded. There have been variations in anticoagulant used for collecting the blood sample, in method employed for harvesting the platelets, and in substrate used for assaying the enzyme. Both citrate and EDTA have been employed as anticoagulants. While citrate may be preferable for 'platelet function tests', EDTA has advantages for biochemical work of the type studied in this review as it lowers ionised calcium concentration sufficiently to prevent platelet aggregation. ${ }^{25}$ With citrate, platelets tend to clump, which may interfere with their preparation. Nor is it known whether any factors are released on aggregation which affect platelet MAO activity. There is no doubt that the method of platelet preparation employed may be important. White et al. $^{26}$ have found specific MAO activity to vary fivefold with changes in the platelet harvesting procedure. Such factors as leucocyte contamination, differences in subpopulation of platelets recovered, or contamination of the platelet plug with plasma protein may all be important. Even the employment of siliconised pipettes can affect the eventual answer. ${ }^{27}$ Most groups prepare a platelet-rich plasma by slow centrifugation of the whole blood; the separated supernatant is then spun at a faster speed to obtain a platelet button, which is washed and stored frozen. There is good evidence, ${ }^{28} 29$ however, that the platelet population is heterogeneous and that large, dense platelets, which sediment more readily, have higher MAO activity per unit protein than the small, lighter ones. Thus, a platelet preparation method that results in large platelets sedimenting with the red cells would seriously distort the specific activity range of the remaining platelets. Although there is individual variation in both platelet and erythrocyte sedimentation rates, the effect on resulting MAO activity has not so far been examined. Murphy et al.30 demonstrated interindividual differences between all platelet fractions in certain subjects. It is possible that some of the recorded pathological changes in platelet MAO activity reflect an altered type of platelet population, and, in such cases, it would be particularly important to harvest as representative a spectrum of the platelets present as possible in their naturally occurring proportions. Control and patient samples should also be collected simultaneously and prepared on the same centrifuge.

Murphy and his colleagues, who have extensive experience in this field, have recently assayed platelet activity in platelet-rich plasma without preparing a platelet button. ${ }^{19}$ Although this simplifies the procedure, it introduces a new variable. Yu and Boulton $^{31}$ have recently shown that plasma can activate platelet MAO substantially, depending on the substrate employed. If this activation phenomenon were to vary in different clinical states, then the direct assay in plasma could compound two different variables.

A wide range of radioactive substrates has been used for this estimation, ${ }^{32}$ but there is no convincing evidence that divergent results between groups derive from this cause, and several studies show a high degree of correlation using different substrates. $^{1933}$ If a molecular variant of MAO were present in a particular individual, its detection might conceivably depend on choice of substrate or on concentration of the particular substrate employed. A low substrate concentration, for example, might detect an enzyme with reduced $\mathrm{K}_{\mathrm{m}}$ and unaltered $V_{\max }$, which a higher concentration would fail to pick up.

Apart from technical differences, another likely explanation for variation is group heterogeneity. A statistical analysis which finds no significant difference between the groups does not prove that they are the same. There may be a subgroup of unknown size among patients with, say, schizophrenia or migraine with low activity. If this were the case, then the results of any one study would depend on the proportion of low subgroup patients included. With small samples more variability 
would be predicted than with larger ones, and the effect would also be more pronounced if the samples being compared were drawn from a different, including racially different, population base. The composition of 'control groups' is also important ( $c f$, the lower activity recorded in hospital professional staff ${ }^{34}$ or military personnel ${ }^{35}$ compared with random controls).

If many independent studies using various assay procedures on material from different patient populations show a similar trend, then the findings become more convincing, as will be seen below: of the six independent studies ${ }^{36-41}$ of migraine, five noted a reduction in platelet activity, significant in four, and in none was there an increase; all five published independent studies, and our unpublished observations on unipolar depression demonstrated an increase in platelet MAO activity. ${ }^{42-46}$ Wyatt and his colleagues ${ }^{24}$ discuss this point in relation to the investigation of schizophrenia. Nineteen out of 26 studies they reviewed showed a statistically significant decrease at the 0.05 level, and the possibility of this happening by chance alone is less than 1 in $10 .{ }^{19}$ Even so, these calculations may be somewhat distorted by the fact that there is a greater tendency to publish positive than negative findings, and, indeed, some more recently published studies have been negative.

\section{MAO activity in normal subjects}

\section{GENETIC INFLUENCE}

Platelet MAO activity is to some extent under genetic control. Nies et al. ${ }^{18}$ compared nine monozygotic twin pairs, 11 dizygotic twin pairs, and 20 age- and sex-matched control pairs and reported that intraclass correlation coefficients followed the order: monozygotic $>$ dizygotic $>$ control. Pandey et al.47 showed that 'between family' variance is greater than that 'within family'. Hussein et al. ${ }^{48}$ similarly noted that intrapair differences are significantly smaller in monozygotic twins compared with controls. None of these studies sheds any light on the mechanism of the genetic control, or how direct or indirect it might be.

\section{EFFECT OF RACE}

A potentially important, but neglected, factor in some of the clinical studies is race. DeLisi ${ }^{49}$ found lymphocyte MAO activity to be significantly less in blacks than in whites, while Groshong et al. ${ }^{6}$ made a similar observation on platelets.

EFFECT OF SEX AND AGE

The single finding that meets with most general agreement is that females have higher platelet MAO activity than males. ${ }^{19} 50$ In monkeys, however, activity appears to be similar in both sexes. ${ }^{50 a}$ In contrast with the earlier claim of Robinson et al. ${ }^{50}$ of a rise with age, Murphy et al. ${ }^{19}$ found that enzyme activity does not change significantly between 10 and 70 years; our own group confirms these data.

The distribution of activity is unimodal, 1947 although Murphy et al. ${ }^{19}$ noted more high and low activity values than would be expected in a normal distribution. The level of platelet MAO activity in normal subjects seems to be fairly constant. ${ }^{18} 19$

HORMONAL CONTROL

Although Belmaker et al. ${ }^{51}$ reported that platelet MAO activity fluctuates during the menstrual cycle, we have failed to confirm this finding (unpublished). It would be surprising if any such effect were a direct one on MAO, for all the available evidence, which undoubtedly shows a progestagenic rise in MAO activity in some organs of the body,,$^{52} 53$ points to this rise occurring solely in MAO A;54 platelet activity only represents MAO B. ${ }^{14}$ Redmond et al. ${ }^{55}$ showed that in male Rhesus monkeys platelet MAO activity is lower during the mating season than outside it, at the time of peak plasma testosterone concentration. Feldman and Roche ${ }^{56}$ found no effect of an oestrogen-progesterone oral contraceptive on platelet MAO activity. They were also unable to find any evidence of abnormal activity in hyperthyroid or hypothyroid patients, ${ }^{57}$ despite earlier changes noted by Levine et al. ${ }^{58}$ in thyrotoxicosis. Adrenaline infusion produces an increase in specific MAO activity. ${ }^{59} 60$ Gentil et al. ${ }^{59}$ suggest that this effect stems from the release of new, more active platelets with higher enzyme activity. We have recently shown that both violent exercise $^{61}$ and noradrenaline infusion provoke a rise in platelet count which is highly correlated with specific MAO activity.

PSYCHOLOGICAL CORRELATION OF PLATELET MAO ACTIVITY IN A NORMAL POPULATION Buchsbaum and coworkers ${ }^{62}$ screened a large population of college students for their platelet MAO activity and were able to identify a subgroup of the population with low activity and an increased vulnerability to psychiatric disorder. The most significant findings were in low MAO males, who had an increased incidence of criminal convictions, while their families showed a greater likelihood of suicide attempts. This group have amplified and extended these observations in several subsequent studies in an attempt to demonstrate correlations between a variety of normal states of behaviour and MAO activity. ${ }^{63-67}$ For example, they reported that the low MAO group spent more time in sensa- 
tion-seeking leisure activities. Although Shaughnessy et $a l ., 68$ in an independent study of adult women, also found some correlation between platelet activity and personality, there was disagreement in detail with Buchsbaum's group.

\section{Platelet MAO in human disease}

\section{SCHIZOPHRENIA}

The initial finding of Murphy and Wyatt ${ }^{69}$ of reduced platelet MAO activity in schizophrenic patients generated much interest, as did their follow-up study 70 of reduced activity in both schizophrenic twins and discordant monozygotic co-twins, suggesting that low platelet MAO activity might be a genetic marker for schizophrenia. Not all the large number of subsequent reports confirmed the original findings however, and considerable controversy now surrounds the subject. To date at least $33^{6} 826333469-100$ separate groups of chronic schizophrenics have been reported upon (some in more than one publication). Twenty reported significant decreases with at least one (but not necessarily all) of the substrates investigated while only one described a significant increase, ${ }^{94}$ in non-hallucinating chronic schizophrenics. Considering all studies on average, schizophrenic platelet MAO activity was reduced by $27 \%$ compared with control. The variability is reduced if schizophrenic patients are separated into those with acute and chronic illness. Eleven of 14 studies $^{42}$ 69-74 77909398 101-103 recorded no difference in acute schizophrenics compared with controls, a finding that should not occasion surprise as there is evidence from family studies that acute, remitting schizophrenia is a disease genetically distinct from chronic schizophrenia. ${ }^{104}$ Initial studies suggested that the paranoid group of chronic schizophrenics have lower platelet MAO activity than control subjects, ${ }^{34} 9192$ but this has not been confirmed by others. ${ }^{6} 95100$ The presence of verbal auditory hallucinations was reported by Schildkraut et al. $^{83}$ and Meltzer et al. ${ }^{99}$ to be associated with statistically significantly low platelet MAO activity, but neither Mann and Thomas $^{95}$ nor Bond et al. ${ }^{94}$ could confirm this finding.

If low MAO activity were a genetic marker for vulnerability to schizophrenia, this might be due to a mutant form of the MAO molecule itself. Belmaker et al. ${ }^{104 a}$ found electrophoretic mobility to be unchanged in platelet enzyme from schizophrenics but the samples tested had normal activity; it seems likely that an aberrant molecule would be present only in individuals with low activity. Belmaker et al. ${ }^{\mathbf{8 6}}$ did note an increased $\mathrm{K}_{\mathrm{m}}$. Murphy et al. ${ }^{105}$ described normal heat stability at $50^{\circ} \mathrm{C}$ and a normal
$\mathbf{K}_{\mathbf{m}}$ in chronic schizophrenics with low MAO activity, although two other papers reported a decrease in $\mathrm{K}_{\mathrm{m}}{ }^{87} 106$ Because of such discrepancies, it would be of great interest if these experiments could be repeated in other laboratories. Studies showing different substrate preferences by platelet MAO in schizophrenics compared with controls ${ }^{73} 91$ also point to the presence of an aberrant enzyme; here, too, it seems important to obtain further data. Berrettini et al.107 noted the presence of an endogenous plasma inhibitor of MAO in their lowactivity schizophrenics, but Wise et al. ${ }^{108}$ were unable to replicate these findings.

As most schizophrenic patients in the published studies were undergoing treatment or had in the past been treated with neuroleptics, while controls were drug-free, any possible effect of neuroleptics on platelet MAO activity becomes important to identify. Murphy and Wyatt ${ }^{69}$ found no significant change in activity in untreated patients compared with those treated for two weeks with phenothiazines. Wyatt et al. ${ }^{70}$ showed platelet MAO activity in the drug-free co-twins to be as low as that in drug-treated schizophrenic twins, both being below control value, suggesting an absence of drug effect. Chlorpromazine treatment failed to change activity in schizophrenics after two weeks ${ }^{95}$ or over six months. ${ }^{33}$ Before we dismiss the possibility of any drug effect completely, however, it is as well to remember that concentrations of chlorpromazine, of the order of those found in brains of treated subjects, will produce a greater than $40 \%$ inhibition in vitro when tested on both MAO A and MAO B of human brain. ${ }^{109}$ Moreover, two groups of investigators have claimed to find lower platelet MAO activity in neuroleptic-treated patients, but Takahashi77 expressed his results in terms of oxidation of 5-hydroxytryptamine, a poor substrate for MAO B, while Friedhoff ${ }^{93}$ prepared his drug-free and drug-treated patients' platelets differently, thus vitiating the results.

INFANTILE AUTISM

Cohen et al., 110 using tyramine as substrate, found that platelet MAO activity in autistic children is not significantly different from that of normal children or adults; Takahashi et al.,111 using 5-hydroxytryptamine, confirmed these findings.

\section{HUNTINGTON'S CHOREA}

Significantly raised platelet MAO activity has been found in two studies of Huntington's chorea.112 113 In the former, a $20 \%$ increase in activity for the whole group was observed, although the values were significantly different from controls only in male patients. In two subjects, improvement in clinical condition was paralleled by a fall in enzyme activity. 
In the second study, 'offspring at risk' also had significantly raised activity, and the authors suggested that the finding might have useful predictive value as a marker of the disease. However, a mean rise of $20 \%$ would suggest a considerable overlap between patients and controls.

\section{AFFECTIVE DISORDERS}

There are good clinical and genetic reasons for dividing affective disorder into bipolar and unipolar subgroups, depending on the presence or absence of a history of mania. ${ }^{114}$ Platelet MAO activity in unipolar patients has consistently been shown to be significantly elevated compared with controls. ${ }^{42-45}$ High values have also been noted in depressed schizophrenics. ${ }^{115}$ Murphy and Weiss ${ }^{46}$ found a $10 \%$ increase, which did not reach statistical significance, in unipolar patients. In no case has a decrease of platelet MAO activity been described in unipolar depression.

The situation is more complex with bipolar depression. Platelet MAO activity in this group has respectively been reported to be significantly decreased, 434546116 increased, ${ }^{4285}$ or not significantly different ${ }^{44} 117$ from control values. Variations in activity seem to have altered with substrate employed, clinical state, ${ }^{43}$ and even, perhaps, with lithium responsiveness; 118 thus, lithium-responsive subjects are reported to have normal platelet MAO activity, and lithium-refractory bipolar patients low activity.

In these studies, many of the patients, unlike controls, were under treatment with lithium or tricyclic antidepressant drugs. None was receiving MAO-inhibiting drugs. Tricyclics have been alleged to depress platelet MAO activity, ${ }^{119}$ but three subsequent papers failed to provide confirmation of this. ${ }^{120-122}$ Although in vitro studies clearly show that this group of drugs produces reversible inhibition, ${ }^{123} 124$ it appears that circulating levels are too low during treatment to produce this effect to any clinically significant degree in vivo, ${ }^{121}$ unless there were a high degree of tissue concentration.

There have been reports that therapeutic blood levels of lithium increase platelet MAO activity. 45125 Berrettini et al.117 and Reveley et al. (submitted for publication) however, found no change in platelet activity during treatment, and Pandey ${ }^{126}$ found a decrease.

\section{ALCOHOLISM}

Sullivan et al. ${ }^{127}$ noted that platelet MAO activity, using tryptamine as substrate, is lower in chronic alcoholics than in controls. This was observed on each of three abstinent intervals over a 12-month time period, suggesting that such low activity is a stable characteristic of this illness, regardless of alcohol consumption. However, both Takahashi ${ }^{128}$ and Brown ${ }^{129}$ found that activity returns to normal as the acute episode of alcoholism subsides. Wiberg ${ }^{130}$ observed a more complex biphasic pattern. Major and Murphy ${ }^{35}$ reported that 99 healthy male alcoholics, in varying stages of abstinence, had significantly lower mean activity than controls; there was no correlation with severity or chronicity of drinking or with duration of abstinence, nor was there a rise to normal values during abstinence, as Wiberg ${ }^{130}$ had found. Alcoholics having a firstdegree relative with this disease had lower activity than those with a negative family history. ${ }^{35}$ Alcohol itself, in the rat at least, does not appear to affect tissue MAO activity in blood concentrations of the order found in human alcoholics. ${ }^{131}$ Nor does acetaldehyde cause a change in platelet MAO activity in vitro in the highest concentrations reported to occur in vivo. ${ }^{131}$

On balance, the evidence thus far suggests that low platelet MAO activity occurs in at least some alcoholics as a stable trait and is not an artefact of ethanol consumption or withdrawal.

\section{MIGRAINE}

Hanington ${ }^{132}$ proposed that there might be a genetic deficiency of MAO in some migrainous patients and that this might account for the reputed ability of tyramine-containing foods such as cheese to initiate attacks. ${ }^{133}$ The tissues of individuals with less oxidative-deaminating activity than normal might allow more tyramine or other amine substrate of MAO into the circulation, to release 5-hydroxytryptamine or noradrenaline from their binding sites. Certainly patients taking MAO-inhibiting drugs may suffer a hypertensive response after eating cheese or other amine-containing food, ${ }^{134}$ although there may be other explanations for this phenomenon. ${ }^{135} 136$ Several independent studies, using different methods, have shown that migrainous patients have a significantly reduced platelet MAO activity of about $50 \%$ compared with controls. ${ }^{36-38}$ Bussone et al., ${ }^{38}$ as foreshadowed by Hanington, ${ }^{137}$ found an even greater reduction in patients with cluster headache. Glover et $a l .^{39}$ noted a small but statistically insignificant decrease in activity in migrainous patients outside an attack, while Thomas ${ }^{40}$ found no difference between 17 patients with classical migraine and a control group.

In a large new study of over 120 headache patients $^{41}$ we have found a significant decrease in activity in men with classical migraine, tension headache, and cluster headache, but no significant change in men with common migraine or in females with any manifestation of the disease compared with 
control. In this study 41 we also showed that MAO activity is relatively stable with repeated assays on the same individual, some over four-year intervals. This was particularly striking in certain subjects with permanently low activity. There was no difference in mean activity of patients taking drugs commonly used in migraine treatment, aspirin, ergotamine, diazepam or clonidine, compared with untreated patients. ${ }^{39}$

Three studies have compared platelet activity in patients with a history of dietary migraine and in those without; ${ }^{37} 3941$ the mean was similar in each. Thus, although more migrainous patients do seem to have lower platelet MAO activity than controls, it is unlikely that any genetic enzymatic deficit can account for most reports of dietary migraine.

Several independent studies have also found significant transitory decreases in platelet MAO activity during a single migraine attack. ${ }^{36} 39138$ However, the transitory reduction in platelet activity may well be a localised platelet effect, deriving perhaps from some circulating non-specific plateletdamaging agent. Pla.elets from migrainous patients aggregate more readily in vitro than control preparations, even outside an attack. ${ }^{139} 140$ Whether any connection exists between low MAO activity and increased aggregability is unknown.

\section{E P I LEPSY}

Kruk et al. ${ }^{141}$ found platelet MAO activity in epileptic patients (mostly idiopathic temporal lobe epilepsy in this particular group) to be significantly higher than in 'neurological' or normal controls; in contrast, Shohnori et al..$^{142}$ observed reduced activity in a small sample of epileptics. Neither study found the enzyme change to be related to EEG abnormality, seizure intensity or frequency, or type and dosage of anticonvulsant drugs.

\section{ESSENTIAL HYPERTENSION}

Anselmi et al. ${ }^{143}$ reported that a group of 31 hypertensive patients had platelet MAO activity values about $40 \%$ lower than those of a control group.

\section{HAEMATOLOGICAL DISEASE}

\section{Iron deficiency anaemia}

Mean platelet MAO activity in patients with iron deficiency anaemia appears to be about $30 \%$ lower than that of normal controls. ${ }^{144}{ }^{145} \mathrm{~A}$ reduction in binding of the irreversible MAO inhibitor, (-)deprenyl, suggests that there is an associated reduction in the number of MAO molecules present.

\section{Megaloblastic anaemia}

Platelet MAO activity is substantially raised in megaloblastic anaemia, ${ }^{146}$ the mean activity in a group of 17 patients being double that of a control group. ${ }^{147}$ Glover et al. ${ }^{147}$ showed MAO activity to be significantly correlated with degree of abnormality as assessed by the dU suppression test or marrow morphology; it fell to normal with treatment and the patients' recovery. The increase was observed both in patients with folate deficiency or vitamin $\mathrm{B}_{12}$ deficiency. Its mechanism, which may be concerned with abnormal platelet size and maturity, remains obscure.

\section{Autoimmune thrombocytopenic purpura and reactive thrombocytosis}

The changes in specific MAO activity described in these two diseases similarly seem likely to be linked with altered platelet population. ${ }^{29}$ In autoimmune thrombocytopenic purpura, platelet count and platelet protein density are both reduced by more than $50 \%$. Specific MAO activity is also reduced by about half. In reactive thrombocytosis, platelet count and platelet protein density are both doubled, and specific MAO activity is also considerably increased. Such correlations between platelet density and MAO activity per unit protein in these diseases are similar to those found for normal platelets.

\section{Discussion}

As we implied in the introduction, most of the literature on this subject is concerned merely with measuring platelet MAO activity in different disease states rather than with more basic research into the causes of any variations discovered. In low MAO activity schizophrenics, there is some evidence that the deficiency is present in other formed elements of the blood such as lymphocytes. ${ }^{90}$ However, no reduction of MAO activity has yet been found in the brain. ${ }^{148}{ }^{149}$ Some possible alterations in $\mathrm{K}_{\mathrm{m}}{ }^{87} 106$ have been noted in schizophrenics but, in general, systematic study of the underlying causes of altered MAO activity has hardly begun. The possibilities are many. Genetically variant forms of the enzyme molecule itself may exist. Different numbers of MAO molecules may be present, perhaps reflecting some primary change in MAO molecules throughout the body or, equally, an abnormal platelet population. It may be that MAO molecules are directly activated or inhibited by small molecule activators or inhibitors. Plasma contains an MAO-activating factor;31 an MAO inhibitor or inhibitors has been demonstrated in human urine, ${ }^{150}$ which may also have some tissue role.

Are the data we have reviewed of any diagnostic or prognostic significance? Even if a mean change in activity is eventually proven unequivocally in any 
disease group, there is such a degree of overlap between patient and control that platelet activity measurements alone are unlikely to be of practical usefulness. Certain outstandingly low values which have emerged in some larger patient surveys ${ }^{39} 62$ may turn out to form a separate cluster of patients for which particular clinical stigmata may yet be identified. Low MAO activity may be associated with a vulnerability to psychiatric disorder in general (with the exception of unipolar depression), and to schizophrenia, alcoholism, and migraine in particular. Even statistical differences between groups can be employed for multifactorial analyses, which may be helpful in demarcating disease categories, the physical bases of which are not understood. If decreases in MAO activity occur solely in the platelet, we need to know what initiates them. If generalised, then we have to determine whether the degree of deficit is sufficient to play a causative role. Nor do we know of any adverse effect of high MAO activity. Our knowledge of the chemical pathology of platelet MAO is still in its infancy.

\section{References}

${ }^{1}$ Costa E, Sandler M. Eds. Monoamine oxidases-new' vistas. New York: Raven Press, 1972.

${ }^{2}$ Wolstenholme GEW, Knight J. Eds. Monoamine oxidase and its inhibition. CIBA Foundation Symposium 39. Amsterdam: Elsevier, Excerpta Medica, North Holland, 1976.

${ }^{3}$ Singer TP, von Korff RW, Murphy DL. Eds. Monoamine oxidase, structure, function, and altered functions. New York: Academic Press, 1979.

${ }^{4}$ Levine RJ, Sjoerdsma A. Monoamine oxidase activity in human tissues and intestinal biopsy specimens. Proc Soc Exp Biol Med 1962;109:225-7.

${ }^{5}$ Challacombe DN, Sandler M, Southgate J. Decreased duodenal monoamine oxidase activity in coeliac disease. Arch Dis Childh 1971;46:213-5.

${ }^{6}$ Groshong R, Baldessarini RJ, Gibson A, Lipinski JF, Axelrod D, Pope A. Activities of types A and B MAO and catechol-O-methyl-transferase in blood cells and skin fibroblasts of normal and chronic schizophrenic subjects. Arch Gen Psychiat 1978;35:1198-205.

? Wurtman RL, Axelrod J. A sensitive and specific assay for the estimation of monoamine oxidase. Biochem Pharmacol 1963;12:1439-41.

${ }^{8}$ Meltzer HY, Arora RC. Skeletal muscle MAO activity in the major psychoses: relationship with platelet and plasma MAO activities. Arch Gen Psychiat 1980;37: 333-9.

9 Bond PA, Cundall RL. Properties of monoamine oxidase (MAO) in human blood platelets, plasma, lymphocytes and granulocytes. Clin Chim Acta 1977;80:317-26.

10 Johnston JP. Some observations upon a new inhibitor of monoamine oxidase in brain tissue. Biochem Pharmacol 1968;17:1285-97.

${ }^{11}$ Knoll J, Magyar K. Some puzzling pharmacological effects of monoamine oxidase inhibitors. In: Costa E, Sandler M, eds. Monoamine oxidases-new vistas. New York: Raven Press, 1972:393-408.
${ }^{12}$ Yang H-YT, Neff NH. $\beta$-Phenylethylamine: a specific substrate for type B monoamine oxidase. $J$ Pharmacol Exp Ther 1973;187:365-71.

${ }^{13}$ Elsworth JD, Glover V, Sandler M. Tele-Methylhistamine is a specific MAO B substrate in man. Psychopharmacology 1980;69:287-90.

1 Donnelly $\mathrm{CH}$, Murphy DL. Substrate- and inhibitorrelated characteristics of human platelet monoamine oxidase. Biochem Pharmacol 1977;26:853-8.

${ }^{15}$ Fowler CJ, Oreland L, Marcusson J, Winblad B. Titration of human brain monoamine oxidase $A$ and $B$ by clorgyline and L-deprenyl. Naunyn-Schmiedeberg's Arch Pharmacol 1980;311:263-72.

${ }^{16}$ Glover V, Elsworth JD, Sandler M. Dopamine oxidation and its inhibition by (-)-deprenyl in man. $J$ Neural Transmiss 1980;Suppl 16:163-72.

17 Winblad B, Gottfries CG, Oreland L, Wiberg A. Monoamine oxidase in platelets and brains of non-psychiatric and non-neurological geriatric patients. Med Biol 1979: 57:129-32.

${ }^{18}$ Nies A, Robinson DS, Lamborn KR, Lampert RP Genetic control of platelet and plasma monoamine oxidase activity. Arch Gen Psychiat 1973;28:834-8.

${ }^{9}$ Murphy DL, Wright C, Buchsbaum M, Nichols A, Costa JL, Wyatt RJ. Platelet and plasma amine oxidase activity in 690 normals: sex and age differences and stability over time. Biochem Med 1976;16:254-65.

${ }^{20}$ McEwen CM, Jr. The soluble monoamine oxidase of human plasma and sera. In: Costa E, Sandler M, eds. Monoamine oxidases-new vistas. New York: Raven Press, 1972:151-65.

21 Bergeret B, Blaschko H, Hawes R. Occurrence of amine oxidase in horse serum. Nature, Lond 1957;180:1127-8.

${ }^{22}$ Lewinsohn R, Böhm K-H, Glover V, Sandler M. A benzylamine oxidase distinct from monoamine oxidase B-widespread distribution in man and rat. Biochem Pharmacol 1978;27:1857-63.

${ }^{23}$ Lewinsohn R, Glover V, Sandler $M$ Development of benzylamine oxidase and monoamine oxidase $A$ and $B$ in man. Biochem Pharmacol 1980;29:1221-30.

24 Wyatt RJ, Potkin SG, Murphy DL. Platelet monoamine oxidase activity in schizophrenia: a review of the data. Am J Psychiat 1979;136:377-85.

2.5 Day HJ, Holmsen H, Zucker MB. Methods for separating platelets from blood and plasma. Thrombo Diathe's Haem 1975;33:648-54.

${ }^{26}$ White HL, McLeod MN, Davidson JRT. Platelet monoamine oxidase activity in schizophrenia. $\mathrm{Am} J$ Psychiat 1976;133:1191-3.

27 Pscheidt GR, Meltzer HY. Siliconizing agent inhibits platelet MAO. Lancet $1976 ; \mathbf{i}: 174$

${ }^{28}$ Corash L, Tan H, Gralnick H. Heterogeneity of human whole blood platelet subpopulations. I. Relationship between buoyant density, cell volume, and ultrastructure. Blood 1977;49:71-7.

${ }^{29}$ Friedhoff AJ, Miller JC, Karpatkin S. Heterogeneity of human platelets. VII. Platelet monoamine oxidase activity in normals and patients with autoimmune thrombocytopenic purpura and reactive thrombocytosis: its relationship to platelet protein density. Blood 1978;51:317-23.

31 Murphy DL, Costa JL, Corash L. Monoamine oxidase activity in different density gradient fractions of human platelets. Psychopharmacology 1978;59:193-7.

${ }^{31} \mathrm{Yu} \mathrm{PH}$, Boulton AA. Activation of platelet monoamine oxidase by plasma in the human. Life Sci 1979;25:31-6.

${ }^{32}$ Tipton KF, Houslay MD, Mantle TJ. The nature and locations of the multiple forms of monoamine oxidase. In: Wolstenholme GEW, Knight J, eds. Monoamine oxidase and its inhibition. CIBA Foundation Symposium 
39. Amsterdam: Elsevier, Excerpta Medica, North Holland, 1976:5-16.

${ }^{33}$ Brockington I, Crow TJ, Johnstone EC, Owen F. An investigation of platelet monoamine oxidase activity in schizophrenia and schizo-affective psychosis. In: Wolstenholme GEW, Knight J, eds. Monoamine oxidase and its inhibition. Ciba Foundation Symposium 39. Amsterdam: Elsevier, Excerpta Medica, 1976:35362.

${ }^{34}$ Berger PA, Ginsberg RA, Barchas JD, Murphy DL, Wyatt RJ. Platelet monoamine oxidase in chronic schizophrenic patients. Am J Psychiat 1978;135:95-9.

${ }^{35}$ Major LF, Murphy DL. Platelet and plasma amine oxidase activity in alcoholic individuals. BrJ Psychiat $1978 ; 132: 548-54$.

${ }^{36}$ Sicuteri F, Buffoni F, Anselmi B, del Bianco PL. An enzyme (MAO) defect on the platelets in migraine. Res Clin Stud Headache 1972;3:245-51.

${ }^{37}$ Sandler M, Youdim MBH, Hanington E. A phenylethylamine oxidizing defect in migraine. Nature, Lond 1974; 250:335-7.

${ }^{38}$ Bussone G, Giovannini P, Boiardi A, Boeri R. A study of the activity of platelet monoamine oxidase in patients with migraine headaches or with 'cluster headaches'. Eur Neurol 1977;15:157-62.

${ }^{39}$ Glover V, Sandler M, Grant E, Rose FC, Orton D, Wilkinson $M$, Stevens $D$. Transitory decrease in platelet monoamine oxidase activity during migraine attacks. Lancet 1977 ; i:391-3.

40 Thomas V. Platelet monoamine oxidase activity in classical migraine. Paper presented at the International Headache Symposium, Florence 1980.

41 Glover V, Peatfield R, Sandler M, Brown G, Craig I, Zammit-Pace R, Gawel M, Rose F Clifford. Amine inactivating enzymes in migrainous patients. Paper presented at the International Migraine Symposium, London 1980.

${ }^{42}$ Nies A, Robinson DS, Harris LS, Lamborn KR. Comparison of monoamine oxidase substrate activities in twins, schizophrenics, depressives, and controls. In: Usdin E, ed. Neuropsychopharmacology of monoamines and their regulatory enzymes. New York: Raven Press, 1974:59-70.

${ }^{43}$ Landowski J, Lysiak W, Angielski S. Monoamine oxidase activity in blood platelets from patients with cyclophrenic depressive syndromes. Biochem Med 1975;14: 347-54.

${ }^{44}$ Edwards DJ, Spiker DG, Kupfer DJ, Foster FG, Neil JF, Abrams L. Platelet monoamine oxidase in affective disorders. Arch Gen Psychiat 1978;35:1443-6.

45 Mann J. Altered platelet monoamine oxidase activity in affective disorders. Psychol Med 1979;9:729-36.

${ }^{46}$ Murphy DL, Weiss R. Reduced monoamine oxidase activity in blood platelets from bipolar depressed patients. Am J Psychiat 1972;128:1351-7.

47 Pandey GN, Dorus E, Shaughnessy R, Davis JM. Genetic control of platelet monoamine oxidase activity: studies on normal families. Life Sci 1979;25:1173-8.

${ }^{48}$ Hussein L, Sindarto E, Goedde HW. Twin studies and substrate differences in platelet monoamine oxidase activity. Hum Hered 1980;30:65-70.

49 DeLisi LE, Neckers LM, Staub RA, Zalcman SJ, Wyatt RJ. Lymphocyte monoamine oxidase activity and chronic schizophrenia. Psychiat Res 1980;2:179-86.

${ }^{50}$ Robinson DS, Davis JM, Nies A, Ravaris CL, Sylvester D. Relation of sex and aging to monoamine oxidase activity of human brain, plasma and platelets. Arch Gen Psychiat 1971;24:536-9.

soa Murphy DL, Redmond DE, Jr, Baulu J, Donnelly CH. Platelet monoamine oxidase activity in 116 normal
Rhesus monkeys: relations between enzyme activity and age, sex and genetic factors. Comp Biochem Physiol 1978;60C:105-8.

${ }^{51}$ Belmaker RH, Murphy DL, Wyatt RJ, Loriaux DL. Human platelet monoamine oxidase changes during the menstrual cycle. Arch Gen Psychiat 1974;31:553-6.

52 Southgate J, Grant EC, Pollard W, Pryse-Davies J, Sandler M. Cyclical variations in endometrial monoamine oxidase: correlation of histochemical and quantitative biochemical assays. Biochem Pharmacol 1968; 17:721-6.

${ }^{53}$ Collins CGS, Pryse-Davies J, Sandler M, Southgate J. Effect of pretreatment with oestradiol, progesterone and DOPA on monoamine oxidase activity in the rat. Nature, Lond 1970;226:642-3.

54 Mazumder RC, Glover V, Sandler M. Progesterone provokes a selective rise of monoamine oxidase $A$ in the female genital tract. Biochem Pharmacol 1980;29: 1857-9.

${ }^{55}$ Redmond DE, Jr, Baulu J, Murphy DL, Loriaux DL, Zeigler MG, Lake CR. The effects of testosterone on plasma and platelet monoamine oxidase (MAO) and plasma dopamine- $\beta$-hydroxylase (DBH) activities in the male Rhesus monkey. Psychosom Med 1976;38: 315-26.

58 Feldman JM, Roche J. Effect of oral contraceptives on platelet monoamine oxidase, monoamine excretion, and adrenocortical function. Clin Pharmac Ther 1976; 20:670-5.

${ }^{57}$ Feldman JM, Roche J. Effect of hyper- and hypothyroidism on platelet monoamine oxidase activity and serotonin metabolism. Metabolism 1977;26:657-64.

${ }^{58}$ Levine RJ, Oates JA, Vendsalu A, Sjoerdsma A. Studies on the metabolism of aromatic amines in relation to altered thyroid function in man. $J$ Clin Endocrinol Metab 1962;22:1242-50.

59 Gentil V, Greenwood MH, Lader MH. The effect of adrenaline on human platelet MAO activity. Psychopharmacologia (Berl) 1975;44:187-90.

${ }^{60}$ Owen F, Acker W, Bourne RC, Frith CD, Riley GJ The effect on human monoamine oxidase activity of subcutaneous injections of adrenaline. Biochem Pharmacol 1977;26:2065-7.

${ }^{61}$ Gawel M, Glover V, Park D, Rose FC, Sandler M. The effect of exercise upon platelet MAO B activity. Clin Sci Mol Med 1977;52:32P.

62 Buchsbaum MS, Coursey RD, Murphy DL. The biochemical high-risk paradigm: behavioral and familial correlates of low platelet monoamine oxidase activity. Science 1976;194:339-41.

63 Buchsbaum MS, Haier RJ, Murphy DL. Suicide attempts, platelet monoamine oxidase and the average evoked response. Acta Psychiat Scand 1977;56:69-79.

${ }^{64}$ Buchsbaum MS, Murphy DL, Coursey RD, Lake CR, Zeigler MG. Platelet monoamine oxidase, plasma dopamine-beta-hydroxylase and attention in a "biochemical high risk" sample. J Psychiat Res 1978;14: 215-24.

${ }^{65}$ Donnelly EF, Murphy DL, Waldman IN, Buchsbaum MS, Coursey RD. Psychological characteristics corresponding to low versus high platelet monoamine oxidase activity. Biol Psychiat 1979;14:375-83.

${ }^{6 B}$ Schooler C, Zahn TP, Murphy DL, Buchsbaum MS. Psychological correlates of monoamine oxidase activity in normals. J Nerv Ment Dis 1978;166:177-86.

${ }^{67}$ Mendelson WB, Buchsbaum MS, Murphy DL, Wyatt RJ, Gillin JC. Platelet monoamine oxidase activity and human sleep. Commun Psychopharmacol 1978;2: 539-44.

${ }^{68}$ Shaughnessy R, Dorus E, Pandey GN, Davis JM. 
Personality correlates of platelet monoamine oxidase activity and red cell lithium transport. Psychiat Res 1980;2:63-74.

${ }^{6 y}$ Murphy DL, Wyatt RJ. Reduced monoamine oxidase activity in blood platelets from schizophrenic patients. Nature, Lond 1972;238:225-6.

i" Wyatt RJ, Murphy DL, Belmaker R, Cohen S, Donnelly $\mathrm{CH}$, Pollin W. Reduced monoamine oxidase activity in platelets: a possible genetic marker for vulnerability to schizophrenia. Science 1973;179:916-7.

${ }^{11}$ Becker RE, Shaskan EG. Platelet monoamine oxidase activity in schizophrenic patients. Am J Psychiat 1977; 134:512-7.

${ }^{72}$ Shaskan EG, Becker RE Platelet monoamine oxidase in schizophrenics. Nature, Lond 1975;253:659-60.

73 Meltzer HY, Stahl SM. Platelet monoamine oxidase activity and substrate preferences in schizophrenic patients. Re's Commun Chem Path Pharmac 1974: 7:419-31.

$\because$ Zeller EA, Boshes B, Davis JM. Molecular aberration in platelet monoamine oxidase in schizophrenia. Lancet $1975 ; \mathbf{i}: 1385$.

75 Owen F, Cross AJ, Crow TJ, Johnstone EC, Lofthouse R, Riley GJ. Platelet monoamine oxidase in schizophrenia. Lancet 1977 ;ii: 1082.

${ }^{76}$ Joseph MH, Owen F, Baker HF, Bourne RC. Platelet serotonin concentration and monoamine oxidase activity in unmedicated chronic schizophrenic and in schizoaffective patients. Psychol Med 1977;7:159-62.

"Takahashi S, Yamane H, Tani N. Reduction of blood platelet monoamine oxidase activity in schizophrenic patients on phenothiazines. Fol Psychiat Neurol Jap $1975 ; 29: 207-14$

is Murphy DL, Belmaker R, Wyatt RJ. Monoamine oxidase in schizophrenia and other behavioral disorders. $J$ Psychiat Res 1974;11:221-47.

79 Murphy DL, Donnelly CH, Miller L, Wyatt RJ. Platelet monoamine oxidase in chronic schizophrenia. Arch Gen Psychiat 1976;33:1377-81.

so Wyatt RJ, Murphy DL. Low platelet monoamine oxidase activity and schizophrenia. Schiz Bull 1976;2:77-89.

${ }^{81}$ Murphy DL, Belmaker R, Carpenter WT, Wyatt RJ. Monoamine oxidase in chronic schizophrenia: studies of hormonal and other factors affecting enzyme activity. BrJ Psychiat 1977;130:151-8.

${ }^{82}$ Wyatt RJ, Potkin SG, Gillin JC, Murphy DL. Enzymes involved in phenylethylamine and catecholamine metabolism in schizophrenics and controls. In: Lipton MA, Di Mascio A, Killam KF, eds. Psychopharmacology: a generation of progress. New York: Raven Press, 1978: 1083-95.

${ }^{83}$ Schildkraut JJ, Herzog SM, Orsulak PJ, Edelman SE, Shein SE, Frozier SH. Reduced platelet monoamine oxidase activity in a subgroup of schizophrenic patients. Am J Psychiat 1976;133:438-40.

${ }^{84}$ Domino EF, Khanna SS. Decreased blood platelet MAO activity in unmedicated chronic schizophrenic patients. Am J Psychiat 1976;133:323-6.

*s Belmaker RH, Ebbesen K, Ebstein R, Rimon R. Platelet monoamine oxidase in schizophrenia and manicdepressive illness. Br J Psychiat 1976;129:227-32.

${ }^{86}$ Belmaker R, Reches A, Ebstein RP. Platelet monoamine oxidase in schizophrenia. Lancet $1977 ; \mathbf{i i}: 821$.

${ }^{87}$ Berrettini WH, Vogel WH, Clouse R. Platelet monoamine oxidase in chronic schizophrenia. Am J Psichiat 1977; 134:805-6.

s Berrettini WH, Prozialeck W, Vogel WH. Decreased platelet monoamine oxidase activity in chronic schizophrenia, shown with novel substrates. Arch G'n Psichiat 1978;35:600-5.
": Sullivan J, Stanfield CN, Dackis C. Platelet MAO activity in schizophrenia and other psychiatric illnesses. Am J Psychiat 1977;134:1098-103.

"Sullivan JL, Cavenar JO, Stanfield CN, Hammett EB. Reduced MAO activity in platelets and lymphocytes of chronic schizophrenics. Am J Psychiat 1978;135:597-8.

91 Demisch L, Mühlen $\mathrm{H}$ von der, Bochnik HJ, Seiler N. Substrate-typic changes of platelet monoamine oxidase activity in sub-types of schizophrenia. Arch Psychia Nervenkr 1977;224:319-29.

4: Potkin SG, Cannon HE, Murphy DL, Wyatt RJ. Are paranoid schizophrenics biologically different from other schizophrenics? New Engl J Med 1978;298:61-6.

${ }^{93}$ Friedhoff AJ, Miller JC, Weisenfreund J. Human platelet MAO in drug free and medicated schizophrenic patients. Am J Psychiat 1978;135:952-5.

"1 Bond PA, Cundall RL, Falloon IRH. Monoamine oxidase (MAO) of platelets, plasma, lymphocytes, and granulocytes in schizophrenia. Br J Psychiat 1979;134 $360-5$.

9; Mann J, Thomas KM. Platelet monoamine oxidase activity in schizophrenia: relationship to disease. treatment, institutionalization and outcome. $\mathrm{Br} J$ Psychiat 1979;134:366-71.

: Ask AL, Böök JA, Heyden T, Ross SB, Unge C, Wetterberg L, Eiduson S, Kobayashi K. Platelet monoamine oxidase in a pedigree with schizophrenia: interlaboratory project. Clin Genet 1979;15:289-99.

${ }^{97}$ Böök JA, Wetterberg L, Modrzewska K. Schizophrenia in a North Swedish geographical isolate, 1900-1977. Epidemiology, genetics and biochemistry. Clin Gene' 1978;14:373-84.

"s van Kammen DP, Marder SR, Murphy DL, Bunney WE. MAO activity, CSF amine metabolites and drug-free improvement in schizophrenia. Am J Psvchiat 1978; 135:567-9.

99 Meltzer HY, Arora RC, Babor R, Jackman H, Nasr S Pscheidt G, Smith M, Strahilevitz M. Platelet monoamine oxidase activity and schizophrenia. Arch $G e n$ Psychiat 1980;37:357.

100 Reveley MA, Gurling HMD, Glass I, Glover V, Sandle $M$. Platelet $\gamma$-aminobutyric-aminotransferase anc monoamine oxidase in schizophrenia Neuropharmacology, in press.

${ }^{101}$ Friedman E, Shopsin B, Sathananthan G, Gershon S Blood platelet monoamine oxidase activity in psychiatric patients. Am J Psychiat 1974;131:1392-4.

102 Carpenter WR Jr, Murphy DL, Wyatt RJ. Platelet monoamine oxidase in acute schizophrenia. $A m \mathrm{~J}$ Psychiat $1975 ; 132: 438-41$.

${ }^{103}$ Cookson IB, Owen F, Ridges PA. Platelet monoamine oxidase activity during the course of schizophreniform psychosis. Psychol Med 1975;5:314-7.

101 Robins E, Guze SB. Establishment of diagnostic validit in psychiatric illness: its application to schizophrenia. Am J Psychiat 1970;126:983-7.

10 a Belmaker RH, Ebstein R, Rimon R, Wyatt RJ, Murphy DL. Electrophoresis of platelet monoamine oxidase in schizophrenia and manic-depressive illness. Acta Psychiat Scand 1976;54:67-72.

${ }^{105}$ Murphy DL, Donnelly CH, Miller L, Wyatt RJ. Platele monoamine oxidase in chronic schizophrenia: some enzyme characteristics relevant to reduced activity. $A r(h$ Gen Psychiat 1976;33:1377-81.

106 Giller EL, Bierer L, Rubinow D, Docherty JP. Platelet MAO $\mathrm{V}_{\max }$ and $\mathrm{K}_{\mathrm{m}}$ in chronic schizophrenic patients. Am J Psychiat 1980;137:97-8

${ }^{107}$ Berrettini WH, Vogel WH Evidence for an endogenous inhibitor of platelet MAO in chronic schizophrenia. Am J Psychiat 1978;135:605-7. 
${ }^{108}$ Wise CD, Potkin S, Bridge P, Wyatt RJ. An endogenous inhibitor of platelet MAO activity in chronic schizophrenia. Failure to replicate. Am J Psychiat 1979;136:1336-7.

${ }^{109}$ Roth JA, Whittemore RM, Shakarjian MP, Eddy BJ. Inhibition of human brain type $A$ and $B$ monoamine oxidase by chlorpromazine and metabolites. Commun Psychopharmacol 1979;3:235-43.

110 Cohen DJ, Young G, Roth JA. Platelet monoamine oxidase in early childhood autism. Arch Gen Psychiat 1977;34:534-7.

111 Takahashi S, Kanai H, Miyamoto Y. Monoamine oxidase activity in blood platelets from autistic children. Fol Psychiat Neurol Jap 1977;31:597-603.

112 Mann J, Chiu E. Platelet monoamine oxidase activity in Huntington's chorea. J Neurol Neurosurg Psychiat $1978 ; 41: 809-12$.

${ }^{113}$ Belendiuk K, Belendiuk GW, Freedman DX. Platelet serotonin and platelet MAO activity in individuals with Huntington's disease. In: Chase TN, Wexler NS, Barbeau A, eds. Advances in neurology, Vol. 23. New York: Raven Press, 1979:473-80.

114 Perris C. A study of bipolar (manic-depressive) and unipolar recurrent depressive psychoses. Acta Psychiat Scand 1966; 42 Suppl 194:1-189.

115 Orsulak PJ, Schildkraut JJ, Schatzberg AF, Herzog JM. Differences in platelet monoamine oxidase activity in subgroups of schizophrenic and depressive disorders. Biol Psychiat 1978;13:637-47.

116 Leckman JF, Gershon ES, Nichols AS, Murphy DL. Reduced platelet monoamine oxidase activity in first degree relatives of individuals with bipolar affective disorders. Arch Gen Psychiat 1977;34:601-6.

117 Berrettini WH, Vogel WH, Ladman RK. Effects of lithium therapy on MAO in manic-depressive illness. Am J Psychiat 1979;136:836-8.

118 Sullivan JL, Cavenar JO, Jr, Maltbie A, Stanfield C. Platelet monoamine oxidase activity predicts response to lithium in manic-depressive illness. Lancet 1977; ii:1325-7.

119 Sullivan JL, Dackis C, Stanfield C. In vivo inhibition of platelet MAO activity by tricyclic anti-depressants. Am J Psychiat 1977;134:188-90.

120 Davidson J, McLeod MN, Linnoila M, Kurland AA, White HL. Platelet MAO inhibition following tricyclic antidepressant therapy. Am J Psychiat 1978;135:603-5.

${ }^{121}$ Reveley MA, Glover V, Sandler M, Coppen A. Absence of platelet monoamine oxidase inhibition during amitriptyline or zimelidine treatment. Br J Clin Pharmac 1979;8:375-8.

122 Giller E, Jr, Jatlow P, Bialos D, Harkness L, Docherty JP. Platelet MAO and amitryptyline treatment. Psychiat Res 1980;2:259-65.

${ }^{123}$ Roth JA, Gillis CN. Deamination of $\beta$-phenylethylamine by monoamine oxidase-inhibition by imipramine. Biochem Pharmacol 1974;23:2537-45.

${ }^{124}$ Edwards DJ, Burns MO. Effects of tricyclic antidepressants upon human platelet monoamine oxidase. Life Sci 1978;15:2045-8.

${ }^{125}$ Bockar J, Roth R, Heninger G. Increased human platelet monoamine oxidase activity during lithium carbonate therapy Life Sci 1975;15:2109-18.

126 Pandey GN, Dorus EB, Dekirmenjian H, Davis JM. Effect of lithium treatment of blood catechol-Omethyltransferase and platelet monoamine oxidase in normal human subjects. Fed Proc 1975;34:778.

127 llivan JL, Stanfield CN, Schanberg S, Cavenar J. Platelet monoamine oxidase and serum dopamine- $\beta$ hydroxylase activity in chronic alcoholics. Arch Gen Psychiat 1978;35:1209-12.
128 Takahashi S, Tani $\mathrm{N}$, Yamane $\mathrm{H}$. Monoamine oxidase activity in blood platelets in alcoholism. Fol Psychiat Neurol Jap 1976;30:455-62.

129 Brown JB. Platelet MAO and alcoholism. Am J Psychiat 1977;134:206-7.

${ }^{130}$ Wiberg $\AA$. Increase in platelet monoamine oxidase activity during controlled abstinence after alcohol abuse. Med Biol 1979;57:133-4.

131 Wiberg $\AA$, Gottfries CG, Oreland L. Low platelet monoamine oxidase in human alcoholics. Med Biol 1977; 55:181-6.

132 Hanington E. Migraine: a blood disorder. Lancet 1978; ii :501-2.

${ }^{133}$ Hanington E, Horn M, Wilkinson M. Furthel observations on the effects of tyramine. In: Cochrane AL, ed. Background to migraine. London: Heinemann, 1970:113-9.

${ }^{134}$ Blackwell B, Marley E, Price J, Taylor D. Hypertensive interactions between monoamine oxidase inhibitors and foodstuffs. Br J Psychiat 1967;113:349-65.

${ }^{135}$ Sandler M, Glover V, Ashford A, Esmail A. The inhibition of tyramine oxidation and the tyramine hypertensive response ("cheese effect") may be independent phenomena. J. Neural Transmiss in press.

136 Sandler M. Deprenyl, monoamine oxidase inhibition and the "cheese effect": some outstanding problems. In: Youdim MBH, Paykel ES, eds. Monoamine oxidase inhibitors - the state of the art. Chichester: Wiley, 1980.

137 Hanington E. Monoamine oxidase and migraine. Lancet $1974 ;$;i: $1148-50$

138 Sandler M, Youdim MBH, Southgate J, Hanington E. The role of tyramine in migraine: some possible biochemical mechanisms. In: Cochrane AL, ed. Background to migraine. London: Heinemann, 1970:104-15.

139 Deshmukh SV, Meyer JS. Cyclic changes in platelet dynamics and the pathogenesis and prophylaxis of migraine. Headache 1977;17:101-8.

140 Couch JR, Hassanein RS. Platelet aggregability in migraine. Neurology 1977;27:843-8

141 Kruk ZL, Moffett A, Scott DF. Platelet monoamine oxidase activity in epilepsy. $J$ Neurol Neurosurg Psychiat $1980 ; 43: 68-70$

${ }^{142}$ Shohnori T, Kaneyuki, T, Kobayashi K, Mori A, Kohsaka M. Reduced blood platelet monoamine oxidase activity in epileptic patients IRCS Med Sci Clin Pharmacol Ther 1975;3:558.

${ }^{143}$ Anselmi B, Buffoni F, Curradi C, del Bianco PL, Sicuteri F. Monoamine oxidase defect in essential arterial hypertension. Monogr Neurol Sci 1976;3:115-23.

144 Callender S, Grahame-Smith DG, Woods HF, Youdim MBH. Reduction of platelet monoamine oxidase activity in iron deficiency anaemia. Br $J$ Pharmacol 1974;52:447P-8P.

145 Youdim MBH, Grahame-Smith DG, Woods HF. Some properties of human platelet monoamine oxidase in iron-deficiency anaemia. Clin Sci Molec Med 1975; 50:479-85.

146 Latt N, Rippey JJ, Stacey RS. Monoamine oxidase of platelets. Br J Pharmacol $1968 ; 32: 427$ P.

147 Glover V, Sandler M, Hughes A, Hoffbrand AV. Platelet monoamine oxidase activity in megaloblastic anaemia. $J$ Clin Pathol, in press.

148 Schwartz MA, Wyatt RJ, Yang H-YT, Neff NH. Multiple forms of brain monoamine oxidase in schizophrenic and normal individuals. Arch Gen Psychiat 1974;31:557-60.

148 Crow TJ, Baker HF, Cross AJ, Joseph MH, Lofthouse R, Longden A, Owen F, Riley GJ, Glover V, Killpack WS. Monoamine mechanisms in chronic schizophrenia: post-mortem neurochemical findings. $B r J$ Psychiat $1979 ; 134: 249-56$. 
150 Glover V, Reveley MA, Sandler M. A monoamine oxidase inhibitor in human urine. Biochem Pharmacol 1980;29:467-70.
Requests for reprints to: Professor M Sandler, Bernhard Baron Memorial Research Laboratories and Insitute of Obstetrics and Gynaecology, Queen Charlotte's Maternity Hospital, Goldhawk Road, London W6 0XG. 